\title{
Ticuna knowledge, Worecü stars and sky movements
}

\author{
Priscila Faulhaber \\ Museu de Astronomia e Ciências Afins (MAST), Rio de Janeiro, Brazil \\ email: pfaulhaber@globo.com
}

\begin{abstract}
This paper focuses on the Ticuna interpretation of the iconography inscribed on ritual artifacts collected by the ethnographer Curt Nimuendaju in the early 1940s. The Ticuna describe certain celestial bodies depicted in the iconography of artifacts that are used in the Ticuna girls' puberty festival as 'Worecü stars'. They relate these stars to various aspects of indigenous mythology expressed in ritual songs and speeches about worecü, a Ticuna word meaning the girl for whom the initiation is being performed. I hold that by incorporating Ticuna mediations into anthropological analysis we enrich this analysis by associating iconic images with mythical meanings transmitted generation by generation through ritual performances in which mythical thinking has the persuasive force of prescriptive action. In thinking about how the Ticuna read the iconography I avoid seeking a strict correlation between Western scientific explanations and the Ticuna's own knowledge about a special star known by them as the Woramacüri star. However, by postulating an association between the Worecü stars and the planets, we can examine the possibility that the Woramacüri Star is correlated with a particular planet at certain times, in specific circumstances.
\end{abstract}

Keywords. ethnology, iconography, cultural heritage, sign language

\section{Introduction}

The Ticuna are the most numerous Amazonian people. They live in the border region between Brazil $(35,000)$, Colombia $(10,000)$ and Peru $(6,000)$. Even though they have had contact with colonial societies ever since the arrival of the Europeans in the region in the 17th century, they maintain their traditions, their language and their main rituals.

Celestial bodies called 'Worecü stars' are depicted in the iconography of artifacts used in the Ticuna girls' puberty festival. These also feature a special star known as the Woramacüri star. The Worecü stars can be related to several aspects of indigenous mythology as expressed in ritual songs and speeches about worecü, a Ticuna word meaning the girl for whom the initiation is being performed. Ticuna narratives on astronomical and meteorological phenomena are significant in the female puberty ritual. During the preparations people observe the movements of the sky in order to anticipate changes in the weather that would affect everyday life.

I understand the reading of iconography to be an interpretive practice of decoding graphic narratives contained in assemblages of iconic designs that contain specific yet highly abstract meaning. Iconographic narratives encapsulate forms of a sign language that can be analyzed according to a certain structure of meaning by decoding a sequence of signs in a sort of 'binary system' where each individual item represents one or other of a pair of opposed states or qualities such as light and dark, above and below, present or absent.

Bearing in mind the limits of commensurability between different forms of knowledge, and in particular between indigenous perceptions and Western astronomy, I avoid looking 
for a strict correlation between Ticuna knowledge about the Woramacüri star and any explanation offered by Western science. Instead, by positing that the Worecü stars are associated with planets, I examine the possibility that the Woramacüri Star is correlated with a specific planet only whenever a particular situation arises.

\section{Cultural astronomy, the anthropology of weather, and the Ticuna social division of the universe}

Cultural astronomy focuses on anthropologically informative meanings that may be found in certain contexts among unfamiliar cultures and by way of cultural comparison. Ruggles and Saunders (1993: 23) distinguish various ways in which particular peoples perceive celestial phenomena and integrate them into their world-view. Since the perceived motions of the sky depend upon cultural perceptions of weather phenomena that can directly affect subsistence, we must also consider the interface between cultural astronomy and the anthropology of weather (Katz et al. 2002).

I understand the Ticuna's perceived role in the cosmos to be predominantly participatory. Bearing in mind Tambiah (1985: 123-166)'s concerns about what is possible in cultural translation, I would interpret their participatory knowledge as an aspect of their religious thinking that anticipates environmental changes by means of the systematic observation of everyday weather phenomena. The ritual prescriptions advise against provoking beings who may cause catastrophes and destruction to local communities. The Ticuna - who value highly their ethnic identity and their own characteristic rituals - say that they seek to live close to the environmental sanctuaries located upstream, at the headwaters of igarapés (narrow branches of rivers), as a way of living in conformity with the will of their cultural heroes. There is also good reason for this in terms of subsistence: the influence of seasonality upon their subsistence activities is more marked along the Solimões River, where, owing to a lack of environmental resources, they are more dependent on the merchants who exploit them. At the headwaters of the igarapés, on the other hand, where the mythical sanctuaries are located, there are plenty of fish and wild game for hunting all year long. Owing to this abundance of natural resources, these mythical territories are the preferred locations for performing the puberty ritual. However, the Ticuna live in contact with modern society, so alongside these long-established practices they have adapted their traditional fish-storage techniques by storing salted fish for commercial use.

\section{Social organization, puberty ceremonies and star lore}

Ticuna society is divided into two exogamous moieties to which the clans belong and which possess certain characteristics. The division into moieties and the clan structures in Ticuna society, in other words, ensure that marriage is only permitted between members of clans belonging to the two different moieties, marriage between people of the same moiety being prohibited as they are considered to be relatives. This rule is strongly respected by the Ticuna. Nimuendaju (1952) pointed out that these moieties correspond to the Ticuna's division of the universe into a 'western' and an 'eastern' part. The complementary relationship between the moieties is a mechanism for consolidating local Ticuna groups' identity.

A girl's parents and relatives perform the puberty festival in order to bring success in agriculture and fishing. Preparations begin after the girl's first menstruation. At this point, her father begins to store manioc flour and meat. The beginning of the dry season is considered to be a good time to prepare for the puberty festival. There is plenty of 
fishing and hunting, and the river has still enough water to enable the 'guests' to get there.

The preferred time for holding the festival is at full moon because the night is illuminated. At dawn the girl, the worecü, is taken from the cubicle in which she has been kept isolated all night, and adorned with a headdress made by the women of the tribes from red macaw feathers to represent the sun's rays. Her hair symbolizes menstrual blood, rain, purification, female fertility, and the empowerment of indigenous people living in their traditional locations (Faulhaber 2009).

The Worecü stars are related to several aspects of Ticuna mythology. According to anthropological literature based on fieldwork analysis, the Ticuna see them as the children of an incestuous relationship between two humanized celestial bodies: the moon (the brother) and the sun (the sister). The story, as told, also referred to a pregnant girl; nobody knew who the father of the child was. Her grandmother told the girl to squeeze some genipap (a tropical fruit), to keep it beside her hammock and use it to stain Moon's face. Following her grandmother's instructions, when Moon came to lay down beside her, she put her hand in the genipap juice and pretending to caress and please him she covered his face with the pigment. This is the reason why, today, we see the moon's face covered with stains. This myth provides a cosmogonic foundation for the Ticuna social organization as a specific ethnic group.

\section{Interpreting cosmological wheels}

In this study, I have used the formal analysis of binary opposites developed in structural anthropology (Lévi-Strauss 1978) to analyze iconography in Amazonian cultures. I have used a comparative approach, taking into account recent studies of the use of symbols to record information in Andean cultures that use binary decoding to analyze devices such as khipus.

Even though the absence of conventionally established phonological value disqualifies iconography as a system of writing (Urton, 2003: 28-29), the identification of Andean khipus and tukapus as 'informational unities' lies in the fact that both can be understood as binary sequences of coded data that conform to certain fixed criteria (ibid.: 49). However, the historical dimension opened up by the ethnography of reading makes it possible to perceive indigenous strategies of depicting information (Salomon 2002; 2006). By encompassing modern groups' own interpretation of iconographic inscriptions, we can improve on the binary method. For example, one may read the absence of a sign, interpreting it according to the current situation.

My contention is that by incorporating Ticuna mediations it is possible to read the iconography by correlating binary codes present both in the iconography itself and in their mythical thinking. My reading is guided, in other words, by the way informants associate iconic images with mythical meanings transmitted down through the generations by ritual performances in which mythical thinking has the persuasive force of prescriptive action. During work sessions that I conducted between 1999 and 2002, the Ticuna expressed their interpretations by commenting on the iconography of artifacts collected by the ethnographer Curt Nimuendaju in 1941 and 1942. Of course, I am cognizant of the historical discontinuities between my informants' own experiences and the situations experienced by the individual artisans who produced these artifacts. However, when verbalizing mental structures of meaning, the Ticuna interpreted the iconic images using the same triggers of mental associations that the artisans had used 60 years earlier. This suggests that the Ticuna interpretation assembles different kinds of narratives that might have been expressing historical meanings by way of their mythical thought. 


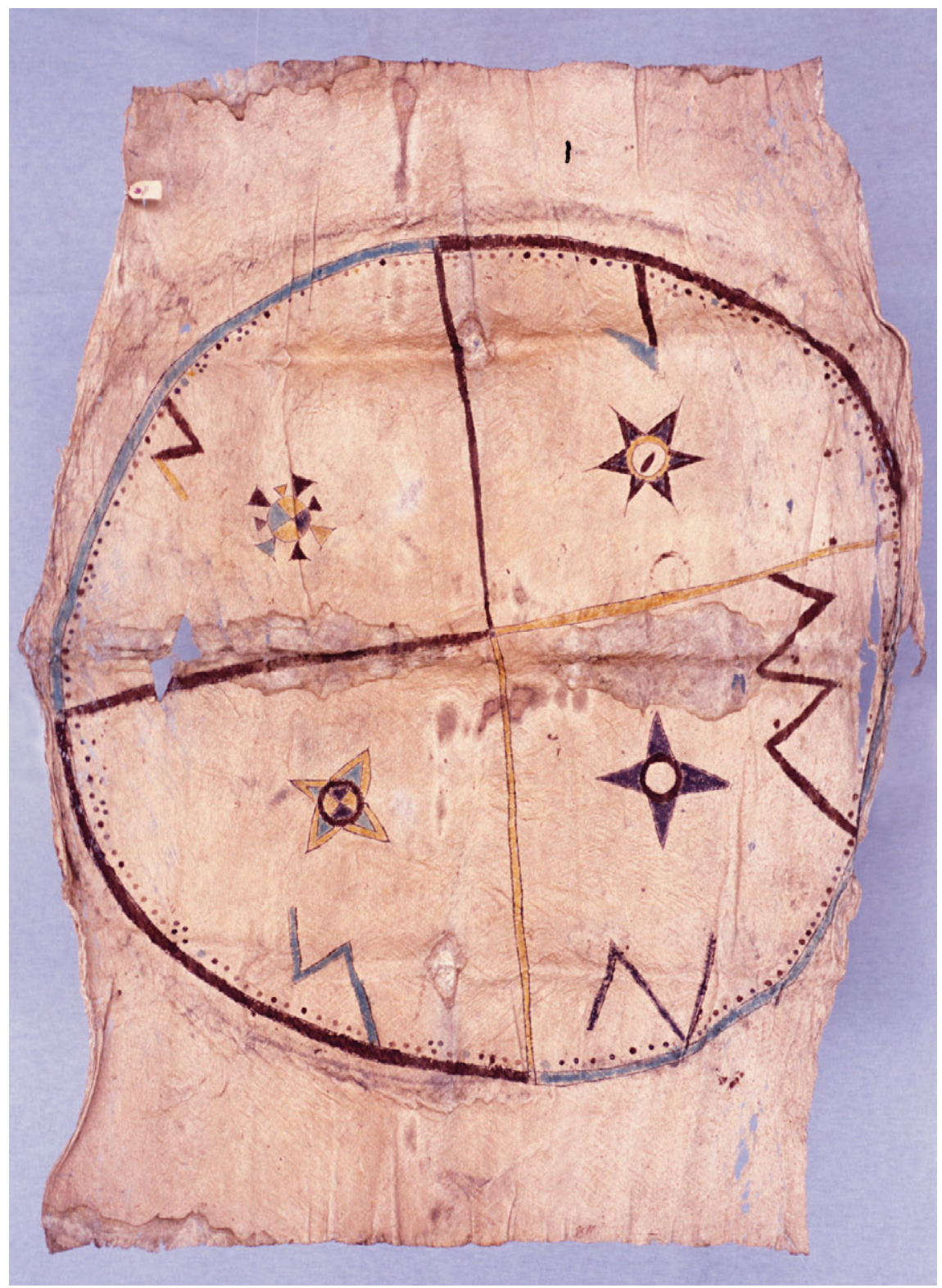

Figure 1. The stars of the world. Goeldi Museum, Nimuendaju Collection, R.G. 4046

One of the artifacts collected by Nimuendaju, 'Cosmological Wheel 4046' (see Fig. 1), contains iconography showing the (spatial) proximity of the three Worecü stars that appeared in 1941 at the beginning of the rainy season close to Coyatchicüra ('Cayman's Jaw'), the Ticuna constellation perceived in the area of sky where we see Taurus. Following the Indigenous interpreters' thinking, I understand the disposition of Wheel 4046 to be an arrangement of fixed constellations and moving celestial bodies. Reading its iconography leads to the supposition that it is related to systematic observations of the opposition between moving celestial bodies and fixed configurations (constellations) throughout time, made in order to anticipate weather phenomena that might have drastic consequences for Ticuna subsistence strategies. 
The title of the picture, 'The stars of the world', is attributed by the Ticuna and conveys the fact that, in their world-view, beings living in the 'upper world' include the younger and older cousins of the Woramacüri star who are the children of the moon. A Ticuna artisan originally designed this wheel in the early 1940s, when Jupiter and Saturn were in Taurus. In 2000, both planets were again in Taurus. The following explanation was given in 1999 by a seventy-year-old elder, respected by the younger Ticuna for his skill in interpreting sky phenomena. Regarding the meaning of the iconography, he surmised that when the picture was produced, the Worecü stars would have been close to the 'Cayman's Jaw' constellation. Reminiscing about the succession of events during his life, he said that he had observed the influence of the Worecü stars on each each adolescent girl secluded for initiation in every puberty ritual he had attended, as well on the whole of the residential group where her extended family lived (which is sometimes smaller than the village, depending on the size of the village) and on everyone invited to attend the festival. On saying this, he stressed the importance of the movements of the celestial bodies for Ticuna life and also stressed the influence of the Worecü stars specifically upon the passage of time between generations.

According to the elder, the first (top left) quadrant of this wheel is associated with Baweta (a collective term for turtles) and the drawing beside the circle is associated with Coyatchicüra (the 'Caiman's Jaw'). In the second (top right) quadrant are the star Woramacuri and again Coyatchicüra. In the third (bottom right) quadrant is Emarutä (Jupiter), Wücütcha (a celestial beast associated with the Jaguar clan), and Coyatchicüra. In the fourth (bottom left) quadrant is Emacüari (Saturn) and Coyatchicüra. An analysis of this wheel attended by the Ticuna, in a planetarium session in the city of Belém in 2002 , led us to confirm the supposition that the wheel is related to the movement of the 'Caiman's Jaw' throughout the year.

A reconstruction of the skyscape shows that Jupiter and Saturn were in the region of Taurus throughout the time between its heliacal rise around June 1941 and its heliacal set around April 1942. Mars passed through the constellation in March and April. We may suppose then, that Wheel 4046 is a non-chronological representation of this relatively static configuration as it was seen in 1942. We may also suppose that the Ticuna artisan had no idea how to represent variability in the sky with the passage of time, but simply wanted to record an unusual phenomenon and its movement about the sky during the time when it occurred. In other words, he was presenting a predetermined configuration that he perceived as a given. His iconographic model was inspired by an esthetic perception associated with the phenomenon's symbolic use, as seen in Gell (1999). In other words, this is artistic expression for social use, since the Ticuna trust that such phenomena are indications of the proper time to perform the girls' puberty ritual, thereby associating the fertility of the girl with nature at large.

In early March 1942, Mars passed close by the Pleiades, so that the association of Jupiter, Saturn, Mars and the Pleiades in the early evening sky would have seemed especially prominent. The correlation between this configuration in the sky and the image that associates the iconography with the Pleiades in the first quadrant of Wheel 4046 is more evident than it is with the other two celestial bodies represented in the quadrants that follow. In the third quadrant the picture shows a celestial body and two constellations around it. A possible reading of this ensemble of images is that it represents the position of Jupiter between the Hyades and Orion, and Mars and Saturn relatively close to the Hyades. Representations of Saturn and Jupiter are quite similar to each other in the indigenous iconography. We can infer that the celestial body in the second quadrant is Mars even though it did not appear as close to the Hyades in actuality as it does in the design. This interpretation is supported by the red tone present on Wheel 4046 . 


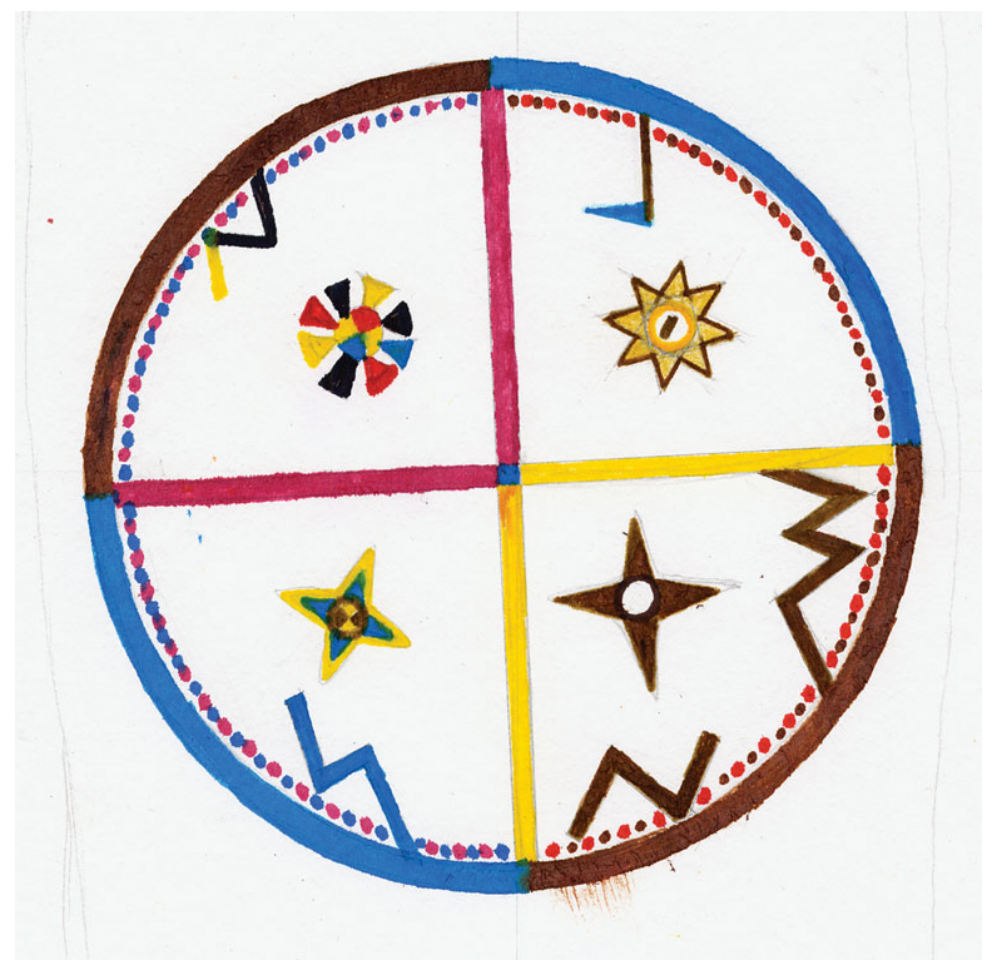

Figure 2. The stars of the world. Design: Lucho Ticuna

In a design delineated in 2002 by the Ticuna Lucho (see Fig. 2), the star in the second quadrant was an eight-pointed star, the same characteristics used to describe Woramacüri, a special Worecü star among the other 'sons of the moon', because its movement in the sky is perceived as quicker than that of the other Worecü stars. Adding this evidence to that already described, it is clearly plausible to associate Woramacüri with Mars.

\section{Conclusion}

Analyzing the symbolism of Ticuna artifacts can help us to understand this people's reading of the skies - a reading that provides them with information about seasonality and weather and helps them to organize their subsistence activities. The correlation between their and our conception about the movements of the celestial bodies is based on systematized knowledge rooted in a somewhat arbitrary consensus resulting from a shared vision of the apparent movement of the celestial bodies.

The Ticuna story about primordial incest shows the significance of the female gender for this people. The girls' puberty festival is correlated with subsistence strategies adapted to the seasonal variability of food stocks, which are affected today by global environmental change. The ritual is linked to fertility and identity: it concerns the group's strategies for handling exhaustible resources, and it is a mechanism of socialization between generations.

The rite of the masks - another Ticuna ritual, which relates to the arrival of rain, winds, gales and storms - expresses their knowledge of the regular cycles of nature, and of weather variability. In order to understand these things with a certain degree of 
predictability, the elders observe the movements of the celestial bodies and correlate what they see with the knowledge passed down to them through mythical stories.

Even among different conceptions of the universe we can find similarities. Both for the Ticuna and for the Western observer, reading the sky implies representing a succession of events. Both for us and for them it is important to know how many moons must pass before a girl becomes a woman and how many times a star must return to the same position in the sky before a person can be respected as an elder. The distinction between generational time, calendrical time and cosmic time has symbolic application.

By examining the correlation between Ticuna narratives on the Woramacüri star as a distinct celestial body among other Worecü stars, as related by informants contemplating the configuration of Wheel 4046, and the actual configuration of the skies in 1941 and 1942, we conclude that when the Ticuna talk today about the Woramacüri star in this specific configuration, we may correlate this celestial body with the planet Mars.

\section{Acknowledgements}

I would like to thank Marcio Campos, Rundsthen Nader, Luis Borges, Ladislao Landa Vásques, Natalia Tourinho and Roberta Dittz for helpful discussions.

\section{References}

Faulhaber, P. 2009, Anthropology of weather and indigenous cosmology inscribed in ritual artifacts. In V. Jankovic \& C. Barbosa (eds), Weather, Local Knowledge and Everyday Life. Issues in Integrated Climate Studies, MAST, Rio de Janeiro, pp. 245-252.

Gell, A. 1999, The Art of Anthropology. Essays and Diagrams, Athlone Press, London \& New Brunswick.

Katz, E., Goloubinoff, M. \& Lammel, A. 2002, Introduction. Éléments pour une anthropologie du climat. In E. Katz, M. Goloubinoff \& A. Lammel (eds), Entre Ciel et Terre. Climat et Sociétés, IRD/Ibis Press, Paris, pp. 15-21.

Lévi-Strauss, C. 1978, Myth and Meaning, Routledge \& Kegan Paul, London.

Nimuendaju, C. 1952, The Tukuna, University of California Press, Berkeley.

Ruggles, C. L. N. \& Saunders, N. J. 1993, The study of cultural astronomy. In C. L. N. Ruggles \& N. J. Saunders (eds), Astronomies and Cultures, University Press of Colorado, Niwot, pp. $1-31$.

Salomon, F. 2002, Patrimonial khipu in a modern Peruvian village. In J. Quilter \& G. Urton (eds), Narrative Threads: Accounting and Recounting in Andean Khipu, Texas University Press, Austin, pp. 293-319.

Salomon, F. 2006, Los Quipocamayos. El Antiguo Arte del Khipu en una Comunidad Campesina Moderna, IFEA/IEP, Lima.

Tambiah, S. J. 1985, Culture, Thought and Social Action, Harvard University Press, Cambridge. Urton, G. 2003, Signs of the Inka Khipu, University of Texas Press, Austin. 